\title{
Prevalensi dan Analisis Faktor Risiko Multidrug Resistance Bakteri Escherichia coli pada Ayam Komersial di Kabupaten Blitar
}

\section{Prevalence and Risk Factors Analysis of Multidrug Resistance of Escherichia coli Bacteria in Commercial Chicken, Blitar District}

\author{
Freshinta Jellia Wibisono ${ }^{1)}$, Bambang Sumiarto ${ }^{2 *}$, Tri Untari ${ }^{3)}$, Mustofa Helmi Effendi ${ }^{4,5)}$, \\ Dian Ayu Permatasari ${ }^{5)}$, Adiana Mutamsari Witaningrum ${ }^{5)}$ \\ 1) Doctoral Program di Sain Veteriner, Fakultas Kedokteran Hewan, Universitas Gadjah Mada, \\ Yogyakarta, Indonesia \\ 2) Departemen Kesehatan Masyarakat Veteriner, Fakultas Kedokteran Hewan, Universitas Gadjah \\ Mada, Yogyakarta, Indonesia \\ 3) Departemen Mikrobiologi, Fakultas Kedokteran Hewan, Universitas Gadjah Mada, Yogyakarta, \\ Indonesia \\ 4) Halal Research Center, Universitas Airlangga, Surabaya, Indonesia \\ ${ }^{5)}$ Departemen Kesehatan Masyarakat Veteriner, Universitas Airlangga, Surabaya, Indonesia
}

Article history

Received: Dec 3, 2019;

Accepted: Mar 15, 2020

* Corresponding author:

Phone: +628156861993

E-mail:pbb@ugm.ac.id

DOI: https://doi.org/10.4654 9/jipvet.v10i1.74

\section{Abstract}

Multidrug resistance is a problem that is difficult to overcome in terms of treating infectious diseases. Multidrug resistance is the term used to describe when a bacteria is resistant to three or more different classes of antibiotics. Escherichia coli as a commensal bacterium which has multidrug resistance, this causes more issues because Escherichia coli can transfer its resistant properties to other bacteria within the poultry digestive tract. The observational study is used to determine the risk factors and to estimate the quantitative effects arising from various components that contribute to the emergence of a disease. The sampling in this study was carried out randomly through cloaca swabs from commercial chicken farms in Blitar and 345 samples were collected. Complementary data collection was carried out using questionnaires, interviews, and field observations. The results showed the incidence of multidrug resistance in commercial chickens in the Blitar District was $72.5 \%$. There is a relationship between causative factors with the incidence of multidrug resistance in Escherichia coli bacteria that is significantly associated with positive risk factors. The strength of this relationship can be seen from the value of $\mathrm{OR}$ and $\mathrm{RR}$, among others factors of chicken breed $(\mathrm{OR}=3.07$; $\mathrm{RR}=1.34)$, breeder's education $(\mathrm{OR}=2.3 ; \mathrm{RR}=1.29)$, type of livestock business $(\mathrm{OR}=7.5 ; \mathrm{RR}=1.43)$, type of animal feed $(\mathrm{OR}=1.91 ; \mathrm{RR}=1.2)$, veterinary support for livestock raising management $(\mathrm{OR}=3.09 ; \mathrm{RR}=1.44)$. The reference variables are whether the antibiotics are administered by non-veterinarians (OR $=2.35)$ or by the TS $(\mathrm{OR}=7.92)$, and whether there is an antibiotic administration program $(\mathrm{OR}=3.16 ; \mathrm{RR}=1.47)$. The overseeing function of farm maintenance, management, and implementation of antimicrobial administration in commercial chicken farms needs to be improved, to increase breeders' awareness of the careful usage of antibiotics and controlling the incidence of antibiotic resistance.

Keywords: Commercial chicken; Escherichia coli; Multidrug resistance; Prevalence 


\section{PENDAHULUAN}

Escherichia coli merupakan bakteri yang banyak terdapat pada saluran cerna dan termasuk dalam kelompok Enterobacteriaceae. Escherichia coli terbagi menjadi dua kelompok utama yaitu strain bakteri komensal dan strain bakteri patogenik (Filho et al., 2015). Escherichia coli secara umum merupakan flora normal pada saluran pencernaan manusia dan hewan, sehingga menjadi salah satu indikator yang sering digunakan untuk pengujian kontaminasi di lingkungan (Evans and Evans, 1996; Brooks et al., 2013). Escherichia coli menjadi salah satu penyebab infeksi pada manusia dan hewan yang dengan mudah dapat menyebabkan resistensi terhadap antibiotik (Paterson and Bonomo, 2005). Resistensi antibiotik menyebabkan penurunan efektivitas pengobatan, peningkatan penularan infeksi, kenaikan mortalitas, dan meningkatkan biaya perawatan kesehatan yang signifikan, sedangkan penemuan antibiotik baru semakin lama semakin sedikit (Handayani et al., 2017).

Kabupaten Blitar merupakan salah satu kabupaten di Jawa Timur yang menjadi sentra peternakan ayam dan telur. Ternak ayam dan produksi telur merupakan kegiatan ekonomi penting di Kabupaten Blitar. Kabupaten Blitar mampu memenuhi $70 \%$ dari kebutuhan telur di Jawa Timur dan secara nasional memenuhi 30 $\%$ kebutuhan telur ayam Nasional (Faishol, 2012). Penyakit pada ayam komersial merupakan salah satu kendala yang berdampak pada penurunan nilai ekonomi karena ayam yang pernah terserang penyakit dapat menjadi sumber penular penyakit (Wiedosari and Wahyuwardani, 2015). Keberadaan Escherichia coli pada ayam komersial dan manajemen pemeliharaan peternakan, berhubungan erat dengan adanya peningkatan penyakit colibacillosis. colibacillosis merupakan penyakit infeksi bakterial yang disebabkan oleh Escherichia coli. Escherichia coli merupakan bakteri oportunistik, yaitu flora normal yang secara alami terdapat pada sistem saluran cerna dalam jumlah yang terkendali, tetapi saat kondisi kekebalan ayam menurun Escherichia coli bisa berkembang menjadi agen patogen (Wahyuwardani et al., 2014). Feses dan lingkungan kandang dapat menjadi tempat keberadaan bakteri Escherichia coli meskipun 16 ayam tidak menunjukkan gejala penyakit apapun akibat keberadaan bakteri ini (WHO, 2018). Penyakit colibacillosis pada ternak ayam dapat meningkatkan kerugian ekonomi dalam jumlah yang tinggi (Wibisono et al., 2018).

Multidrug resistance adalah resistensi terhadap tiga atau lebih golongan antibiotik yang berbeda (Handayani et al., 2017). Escherichia coli sebagai bakteri komensal yang bersifat multidrug resistance dapat menjadi masalah kesehatan, karena Escherichia coli mampu mentransfer gen resisten ke bakteri patogen lain dalam saluran cerna (Masruroh et al., 2016). Pencegahan meluasnya bakteri resisten di peternakan ayam komersial penting dilakukan dalam upaya untuk mewaspadai peningkatan resistensi antibiotik di peternakan ayam. Penelitian untuk memperoleh informasi mengenai kejadian dan faktor risiko yang berhubungan dengan resistensi antibiotik bakteri Escherichia coli pada ayam komersial di Kabupaten Blitar perlu untuk dilakukan. Pengukuran kejadian masalah kesehatan di lapangan menunjukkan besar angka kejadian yang terdapat pada kelompok hewan yang terserang. Hasil pengukuran frekuensi masalah kesehatan sangat berguna apabila diterapkan pada pengendalian dan penanganan penyakit pada populasi (Sumiarto dan Budiharta, 2018).

\section{MATERI DAN METODE}

Sampel yang digunakan pada penelitian ini sebanyak 345 sampel swab kloaka ayam dari peternakan ayam komersial di Kabupaten Blitar. Definisi peternakan ayam komersial merupakan peternakan ayam layer dan peternakan ayam broiler. Sampel berasal dari 7 kecamatan di Kabupaten Blitar, yaitu Kecamatan Srengat, Ponggok, Udanawu, Talun, Kademangan, Bakung, dan Garum. Jumlah sampel tiap kecamatan ditentukan secara proporsional, dengan pengambilan sampel secara random, agar semua anggota populasi mempunyai kesempatan yang sama untuk dipilih (Martin et al., 1987; Sumiarto dan Budiharta, 2018). Besaran sampel dihitung menggunakan rumus prevalensi penyakit yaitu $\mathrm{n}=4 \mathrm{PQ} / \mathrm{L}^{2}$, dengan $\mathrm{n}=$ besaran sampel, $\mathrm{P}=$ asumsi tingkat kejadian di daerah penelitian, $\mathrm{Q}$ $=$ perhitungan $1-\mathrm{P}$ dan $\mathrm{L}=$ galat yang 
diinginkan pada penelitian (5\%). Isolat positif Escherichia coli pada sampel swab kloaka ayam kemudian dilakukan uji kepekaan antibiotik pada agar Mueller-Hinton agar (Merck, Jerman), sesuai rekomendasi dari Clinical Laboratory Standard Institute (CLSI, 2017) menggunakan disk antibiotik golongan beta lactam (ampicillin 10 $\mu \mathrm{g}$ ), golongan aminoglikosida (streptomycin $10 \mu \mathrm{g}$ ), golongan

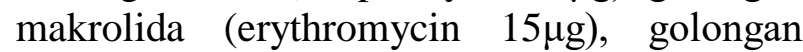
tetrasiklin (tetracycline $30 \mu \mathrm{g}$ ), dan golongan sulfonamide (sulfamethoxazole-trimethoprim $25 \mu \mathrm{g})$. Biakan tersebut diinkubasi pada suhu 35-37 ${ }^{\circ} \mathrm{C}$ selama $18-24$ jam. Hasil evaluasi setelah diinkubasi menunjukkan adanya zona hambat yang muncul pada cawan diinterpretasi berdasarkan panduan CLSI yaitu Sensitif, intermediate, dan resisten (CLSI, 2017; Effendi et al., 2018). Pengumpulan data pelengkap dilakukan menggunakan kuesioner, observasi lapangan, dan wawancara kepada peternak dilokasi pengambilan sampel. Variabel penelitian meliputi aspek ternak, peternak, manajemen pemeliharaan, dan aspek penggunaan antibiotik. Analisis data dilakukan dengan analisis bivariat asosiasi dan kekuatan asosiasi faktor penyakit terhadap kejadian penyakit, menggunakan perangkat lunak statistix8.

\section{HASIL DAN PEMBAHASAN}

Kejadian multidrug resistance pada ayam komersial di Kabupaten Blitar (Tabel 1) menunjukkan prevalensi kejadian pada tingkat ternak sebesar $72,5 \%$, dengan prevalensi kejadian pada ayam layer sebesar $62,7 \%$ dan pada ayam broiler sebesar 83,75\%. Ternak ayam komersial di Kabupaten Blitar menunjukkan adanya resistensi terhadap golongan beta lactam $(79,4 \%)$, golongan aminoglikosida (69\%), golongan makrolida $(73,9 \%)$, golongan tetrasiklin $(45,8 \%)$, dan golongan sulfonamide potensial $(67 \%)$.

\section{Tabel 1. Multidrug resistance bakteri Escherichia coli di Kabupaten Blitar}

\begin{tabular}{ccccc} 
& \multicolumn{4}{c}{ Multi-Drug Resistant } \\
& Positif & \% & Negatif & \% \\
Ternak layer $(\mathrm{n}=185)$ & 116 & 62,70 & 69 & 37,30 \\
Ternak broiler $(\mathrm{n}=160)$ & 134 & 83,75 & 26 & 16,25 \\
Ternak komersial $(\mathrm{n}=345)$ & 250 & 72,50 & 95 & 27,50
\end{tabular}

Tingginya kejadian multidrug resistance pada peternakan komersial di Kabupaten Blitar ini, sesuai dengan penelitian sebelumnya yang menyebutkan tingkat kejadian resistensi antibiotik pada peternakan ayam broiler di Kabupaten Subang sebesar 93,2\% telah resisten terhadap lebih dari 2 jenis antibiotik dan multidrug resistance dengan persentase tertinggi pada resistensi terhadap 4 jenis antibiotik yakni sebesar 40,5\% (Niasono et al., 2019). Hasil resistensi multidrug resistance yaitu kepekaan bakteri Escherichia coli terhadap lebih dari 3 golongan antibiotik. Sifat multidrug resistance pada antibiotik, termasuk golongan beta laktam, streptomycin, dan tetracycline, sering ditemukan pada Salmonella sp. dan Escherichia coli (Erviani, 2013).

Tabel 2. Analisis bivariat variabel ternak dan peternak

\begin{tabular}{|c|c|c|c|c|c|c|c|}
\hline Faktor risiko & Variabel & D+ & D- & $\chi^{2}$ & p-value & OR & $\mathbf{R R}$ \\
\hline Spesies ternak & $\begin{array}{l}\text { Broiler } \\
\text { Layer }\end{array}$ & $\begin{array}{l}134 \\
116\end{array}$ & $\begin{array}{l}26 \\
69\end{array}$ & 19,05 & 0,0000 & 3,07 & 1,34 \\
\hline Pendidikan & $\begin{array}{l}\text { Non Perguruan Tinggi } \\
\text { Perguruan Tinggi }\end{array}$ & $\begin{array}{r}186 \\
64\end{array}$ & $\begin{array}{l}53 \\
42\end{array}$ & 11,20 & 0,0008 & 2,3 & 1,29 \\
\hline
\end{tabular}

Kejadian multidrug resistance pada Escherichia coli berhubungan dengan beberapa variabel faktor risiko, salah satunya adalah dari faktor spesies ternak, yaitu ternak ayam broiler dan ternak ayam layer. Nilai signifikansi $\mathrm{P}=$ 0,0000 ( $\mathrm{P}<0,05)$ menggunakan Pearson's chisquare $(\chi 2)$ dengan nilai $\chi 2$ hitung 19,05 lebih besar daripada $\chi 2$ tabel $(3,84)$ maka Hipotesa 
awal $\left(\mathrm{H}_{0}\right)$ ditolak dan Hipotesa akhir $\left(\mathrm{H}_{1}\right)$ diterima (Tabel 2). Hasil signifikansi menunjukkan bahwa terdapat hubungan antara kejadian multidrug resistance pada Escherichia coli dengan variabel spesies ternak (broiler maupun layer). Kekuatan hubungan tersebut dapat dilihat dari nilai Odds ratio $(\mathrm{OR})$ maupun Relative Risk (RR), dengan nilai $\mathrm{OR}=3,07$ yang berarti bahwa kejadian multidrug resistance bakteri Escherichia coli pada ayam broiler 3 kali lebih besar daripada ternak ayam layer, sedangkan nilai $\mathrm{RR}=1,34$ menunjukkan bahwa risiko kejadian multidrug resistance bakteri Escherichia coli pada ternak ayam broiler 1,34 kali lebih berisiko daripada ternak ayam layer.

Variabel peternak yang menjadi faktor risiko kejadian multidrug resistance bakteri Escherichia coli yaitu dari segi pendidikan. Faktor pendidikan peternak terbagi menjadi 4 tingkatan yaitu pendidikan SD, SMP, SMA dan Perguruan Tinggi, yang dikelompokkan menjadi dua variabel yaitu pendidikan Perguruan Tinggi dan pendidikan selain perguruan tinggi (termasuk tingkat pendidikan SD, SMP, dan SMA). Faktor pendidikan memiliki nilai signifikansi $\mathrm{P}=0,0008(\mathrm{P}<0,05)$ dan nilai $\chi 2$ hitung $=11,20$ lebih besar daripada $\chi 2$ tabel $(3,84)$ maka Hipotesa awal $\left(\mathrm{H}_{0}\right)$ ditolak dan Hipotesa akhir $\left(\mathrm{H}_{1}\right)$ diterima (Tabel 2).
Hasil signifikansi ini menunjukkan bahwa terdapat hubungan antara faktor pendidikan dengan kejadian multidrug resistance pada Escherichia coli. Kekuatan hubungan tersebut memiliki nilai $\mathrm{OR}=2,3$ dan $\mathrm{RR}=1,29$. Interpretasi hasil dari nilai OR menunjukkan bahwa kejadian multidrug resistance bakteri Escherichia coli 2,3 kali lebih besar pada peternak yang berpendidikan non perguruan tinggi dibandingkan dengan peternak yang memiliki pendidikan perguruan tinggi.

Manajemen pemeliharaan peternakan (Tabel 3) menjadi salah satu variabel yang dapat menyebabkan kejadian multidrug resistance pada Escherichia coli. Faktor ini meliputi jenis usaha peternakan (kemitraan maupun mandiri), yang berdasarkan analisis bivariat memiliki nilai signifikansi $\mathrm{P}=0,0000$ $(\mathrm{P}<0,05)$ dengan nilai $\chi 2$ hitung 26,58 lebih besar daripada $\chi 2$ tabel $(3,84)$ maka Hipotesa awal $\left(\mathrm{H}_{0}\right)$ ditolak dan Hipotesa akhir $\left(\mathrm{H}_{1}\right)$ diterima (Tabel 3). Hasil signifikansi menunjukkan bahwa terdapat hubungan antara kejadian multidrug resistance bakteri Escherichia coli dengan jenis usaha peternakan ayam (kemitraan maupun mandiri), dengan nilai $\mathrm{OR}=7,51$ menunjukkan bahwa kejadian multidrug resistance bakteri Escherichia coli pada usaha ternak kemitraan 7,51 kali lebih besar daripada usaha ternak mandiri.

Tabel 3. Analisis bivariat variabel manajemen pemeliharaan

\begin{tabular}{|c|c|c|c|c|c|c|c|}
\hline Faktor risiko & Variabel & D+ & D- & $\chi^{2}$ & p-value & OR & RR \\
\hline Jenis Usaha & $\begin{array}{c}\text { Kemitraan } \\
\text { Mandiri }\end{array}$ & $\begin{array}{c}84 \\
166\end{array}$ & $\begin{array}{c}6 \\
89\end{array}$ & 26,58 & 0,0000 & 7,51 & 1,43 \\
\hline Pakan & $\begin{array}{c}\text { Buatan pabrik } \\
\text { Racikan peternak }\end{array}$ & $\begin{array}{c}163 \\
87\end{array}$ & $\begin{array}{l}47 \\
48\end{array}$ & 7,15 & 0,0075 & 1,91 & 1,2 \\
\hline $\begin{array}{c}\text { Dukungan } \\
\text { dokter hewan }\end{array}$ & $\begin{array}{l}\text { Tidak ada } \\
\text { Ada }\end{array}$ & $\begin{array}{c}199 \\
51\end{array}$ & $\begin{array}{l}53 \\
42\end{array}$ & 19,82 & 0,0000 & 3,09 & 1,44 \\
\hline $\begin{array}{c}\text { Sanitasi } \\
\text { kebersihan }\end{array}$ & $\begin{array}{l}\text { Kurang bersih } \\
\text { Bersih }\end{array}$ & $\begin{array}{c}153 \\
97\end{array}$ & $\begin{array}{l}39 \\
56\end{array}$ & 11,32 & 0,0008 & 2,26 & 1,26 \\
\hline $\begin{array}{l}\text { Treatmen air } \\
\text { minum }\end{array}$ & $\begin{array}{c}\text { Ada }+ \text { klorin } \\
\text { Tidak ada }\end{array}$ & $\begin{array}{l}131 \\
119\end{array}$ & $\begin{array}{l}36 \\
59\end{array}$ & 5,80 & 0,0160 & 1,8 & 1,17 \\
\hline & $\begin{array}{l}\text { Diendapkan } \\
\text { Tidak }\end{array}$ & $\begin{array}{l}103 \\
147\end{array}$ & $\begin{array}{l}49 \\
46\end{array}$ & 3,01 & 0,0828 & - & - \\
\hline
\end{tabular}

Variabel kemitraan berhubungan dengan adanya rencana program pemberian antibiotik pada ternak sebagai terapi pencegahan penyakit. Variabel program pemberian antibiotik pada ternak ayam terhadap kejadian multidrug resistance bakteri Escherichia coli memiliki nilai signifikansi $\mathrm{P}=0,0000(\mathrm{P}<0,05)$ dengan nilai $\chi 2$ hitung 19,13 lebih besar dari pada $\chi 2$ tabel $(3,84)$ maka Hipotesa awal $\left(\mathrm{H}_{0}\right)$ ditolak dan Hipotesa akhir $\left(\mathrm{H}_{1}\right)$ diterima (Tabel 4). Hasil signifikansi menunjukkan bahwa terdapat hubungan antara variabel adanya program 
pemberian antibiotik dengan kejadian multidrug resistance pada Escherichia coli, dengan nilai $\mathrm{OR}=3,16$ menunjukkan bahwa kejadian multidrug resistance bakteri Escherichia coli pada ternak dengan program pemberian antibiotik 3,16 kali lebih besar daripada ternak yang tidak menggunakan program pemberian antibiotik, sedangkan nilai $\mathrm{RR}=1,47$ menunjukkan bahwa risiko kejadian multidrug resistance bakteri Escherichia coli pada ternak dengan program pemberian antibiotik 1,47 kali lebih berisiko daripada yang tidak menggunakan program pemberian antibiotik.

Tabel 4. Analisis bivariat variabel pemberian antibiotik

$\begin{array}{cccccccc}\text { Faktor risiko } & \text { Variabel } & \text { D+ } & \text { D- } & \boldsymbol{\chi}^{\mathbf{2}} & \text { p-value } & \text { OR } & \text { RR } \\ \text { Program } & \text { Ada } & 208 & 58 & 19,13 & 0,0000 & 3,16 & 1,47 \\ \text { antibiotik } & \text { Tidak ada } & 42 & 37 & & & & \\ & \text { Bukan dokter hewan } & 217 & 70 & 8,47 & 0,0036 & 2,35 & 1,33 \\ \text { Referensi } & \text { Dokter hewan } & 33 & 25 & & & & \\ \text { pemberian } & \text { Technical Service } & 87 & 6 & 28,37 & 0,0000 & 7,92 & 1,45 \\ & \text { Bukan Technical Service } & 163 & 89 & & & & \end{array}$

Pakan ternak yang diberikan pada ternak ayam meliputi pakan buatan pabrik dan pakan racikan peternak. Variabel pakan ternak memiliki nilai signifikansi $\mathrm{P}=0,0075(\mathrm{P}<0,05)$ dengan nilai $\chi 2$ hitung 7,15 lebih besar daripada $\chi 2$ tabel $(3,84)$ maka Hipotesa awal $\left(\mathrm{H}_{0}\right)$ ditolak dan Hipotesa akhir $\left(\mathrm{H}_{1}\right)$ diterima (Tabel 3). Hasil ini menunjukkan bahwa terdapat hubungan antara kejadian multidrug resistance bakteri Escherichia coli dengan variabel jenis pakan ternak, dengan nilai $\mathrm{OR}=1,91$ menunjukkan bahwa kejadian multidrug resistance bakteri Escherichia coli pada ayam yang diberi pakan buatan pabrik 1,91 kali lebih besar daripada pakan racikan sendiri, sedangkan nilai $\mathrm{RR}=1,2$ menunjukkan bahwa risiko kejadian multidrug resistance bakteri Escherichia coli pada ternak dengan pakan buatan pabrik berisiko 1,2 kali lebih besar daripada pakan racikan sendiri. Hasil analisis ini mendukung penelitian terdahulu yang menunjukkan bahwa hampir semua pabrik pakan menambahkan antibiotika ke dalam pakan komersial, sehingga sebagian besar pakan komersial yang beredar di Indonesia mengandung antibiotik (Bahri et al., 2005).

Dukungan dokter hewan pada peternakan ayam menjadi salah satu faktor risiko kejadian multidrug resistance bakteri Escherichia coli pada peternakan (Tabel 3). Tidak semua peternakan memiliki dukungan dokter hewan dalam manajemen permeliharaan peternakannya. Faktor ada dan tidak adanya dukungan dokter hewan ini memiliki nilai signifikansi $\mathrm{P}=0,0000(\mathrm{P}<0,05)$ dengan nilai $\chi 2$ hitung 19,82 lebih besar daripada $\chi 2$ tabel $(3,84)$, maka Hipotesa awal $\left(\mathrm{H}_{0}\right)$ ditolak dan Hipotesa akhir $\left(\mathrm{H}_{1}\right)$ diterima. Analisis bivariat menunjukkan bahwa terdapat hubungan antara faktor dukungan dokter hewan dalam manajemen pemeliharaan peternakan dengan kejadian multidrug resistance bakteri Escherichia coli, dengan nilai OR $=3,09$ menunjukkan bahwa kejadian multidrug resistance bakteri Escherichia coli pada peternakan yang tidak memiliki dukungan dokter hewan adalah 3 kali lebih besar daripada yang memiliki dukungan dokter hewan pada manajemen pemeliharaan peternakannya (Tabel 3). Dokter hewan pada peternakan unggas komersial kurang berperan karena pada umumnya peran tersebut lebih banyak dilakukan oleh tenaga jasa pelayanan (technical services/TS) dari berbagai perusahaan (Iqbal, 2016).

Variabel referensi pemberian antibiotik pada ternak ayam terhadap kejadian multidrug resistance bakteri Escherichia coli oleh TS vs non TS memiliki nilai signifikansi $\mathrm{P}=0,0000$ $(\mathrm{P}<0,05)$, sedangkan pemberian referensi antibiotik oleh dokter hewan vs non dokter hewan memiliki nilai signifikansi $\mathrm{P}=0,0036(\mathrm{P}$ $<0,05)$. Hasil signifikan ini menunjukkan bahwa terdapat hubungan antara referensi pemberian antibiotik terhadap kejadian multidrug resistance pada Escherichia coli. Kekuatan hubungan variabel referensi pemberian antibiotik selain dokter hewan 
memiliki nilai $\mathrm{OR}=2,35$, hal ini menunjukkan bahwa kejadian multidrug resistance bakteri Escherichia coli pada ternak dengan referensi pemberian antibiotik selain dokter hewan 2,35 kali lebih besar daripada referensi pemberian antibiotik oleh dokter hewan. Sedangkan pada variabel referensi pemberian antibiotik oleh TS memiliki nilai $\mathrm{OR}=7,92$, hal ini menunjukkan bahwa kejadian multidrug resistance bakteri Escherichia coli pada ternak dengan referensi pemberian antibiotik oleh TS adalah 8 kali lebih besar daripada referensi pemberian antibiotik selain TS.

Sanitasi kebersihan kandang pada ternak ayam menjadi salah satu faktor risiko kejadian multidrug resistance bakteri Escherichia coli (Tabel 3), dengan nilai signifikansi $\mathrm{P}=0,0008$ $(\mathrm{P}<0,05)$ dengan nilai $\chi 2$ hitung 11,32 lebih besar daripada $\chi^{2}$ tabel $(3,84)$, maka Hipotesa awal $\left(\mathrm{H}_{0}\right)$ ditolak dan Hipotesa akhir $\left(\mathrm{H}_{1}\right)$ diterima. Analisis bivariat terhadap kejadian multidrug resistance bakteri Escherichia coli menunjukkan bahwa terdapat hubungan antara sanitasi kebersihan kandang dengan kejadian multidrug resistance bakteri Escherichia coli. Kekuatan hubungan memiliki nilai $\mathrm{OR}=2,26$ menunjukkan bahwa kejadian multidrug resistance bakteri Escherichia coli pada peternakan yang memiliki sanitasi kandang kurang bersih adalah 2,26 kali lebih besar daripada yang memiliki sanitasi kandang bersih. Sanitasi kebersihan kandang merupakan usaha untuk mencegah penyebaran penyakit dengan menjaga kebersihan kandang, peralatan dan lingkungan (Larson, 2013).

Perlakuan pada air minum yang diberikan pada ternak di peternakan pada umum nya ada dua perlakuan yaitu ada nya perlakuan pengendapan air minum dan adanya pemberian klorin pada air minum ternak. Variabel perlakuan pengendapan air minum pada kejadian multidrug resistance bakteri Escherichia coli (Tabel 3), memiliki nilai signifikansi $\mathrm{P}=0,0828(\mathrm{P}>0,05)$ dengan nilai $\chi^{2}$ hitung 3,01 lebih kecil daripada $\chi^{2}$ tabel $(3,84)$, maka Hipotesa awal $\left(\mathrm{H}_{0}\right)$ diterima dan Hipotesa akhir $\left(\mathrm{H}_{1}\right)$ ditolak. Hasil analisis ini menunjukkan bahwa tidak terdapat hubungan antara perlakuan pengendapan air minum dengan kejadian multidrug resistance bakteri Escherichia coli. Sedangkan pada perlakukan pemberian klorin pada air minum ternak, menunjukkan nilai signifikansi $\mathrm{P}=0,0160(\mathrm{P}<$ $0,05)$ dengan nilai $\chi 2$ hitung 5,80 lebih besar daripada $\chi^{2}$ tabel $(3,84)$, maka Hipotesa awal $\left(\mathrm{H}_{0}\right)$ ditolak dan Hipotesa akhir $\left(\mathrm{H}_{1}\right)$ diterima. Analisis bivariat terhadap kejadian multidrug resistance bakteri Escherichia coli menunjukkan bahwa terdapat hubungan antara pemberian klorin pada air minum ternak dengan kejadian multidrug resistance bakteri Escherichia coli. Kekuatan hubungan memiliki nilai $\mathrm{OR}=1,8$ menunjukkan bahwa kejadian multidrug resistance bakteri Escherichia coli pada peternakan yang memberikan perlakuan air minum dengan menambahkan klorin adalah 1,8 kali lebih besar daripada yang tidak memberikan klorin pada air minum ternaknya. Klorin sebagai desinfeksi air digunakan untuk membunuh bakteri dalam air minum ternak dapat memfasilitasi penyebaran resistensi antimikroba pada bakteri. Penelitian sebelumnya menunjukkan bahwa isolat bakteri telah resisten terhadap klorin, dan isolat tersebut memiliki tingkat resistensi yang bervariasi terhadap ampisilin tetapi $100 \%$ resisten terhadap trimethoprim, streptomisin, kanamisin, dan tetrasiklin (Kusuma and Waturangi, 2007). Desinfeksi menggunakan bahan kimia atau desinfektan. Penggunaan antimikroba (antibiotik, desinfektan, dan antiseptik) yang tidak sesuai dapat menimbulkan percepatan resistensi antimikroba (AMR) pada manusia, hewan, dan lingkungan (Larson, 2013).

\section{KESIMPULAN}

Kejadian multidrug resistance bakteri Escherichia coli pada ayam komersial di Kabupaten Blitar menunjukkan prevalensi kejadian tingkat ternak sebesar 72,5\%. Faktor risiko yang berasosiasi positif terhadap kejadian Multidrug resistance pada bakteri Escherichia coli antara lain faktor jenis ternak ayam, pendidikan peternak, jenis usaha peternakan, jenis pakan ternak, dukungan dokter hewan pada manajemen pemeliharaan ternak, sanitasi kebersihan kandang, treatment pemberian klorin pada air minum, adanya program pemberian antibiotik, dan referensi penggunaan antibiotik. 


\section{DAFTAR PUSTAKA}

Bahri, S., E. Masbulan, \& A. Kusumaningsih. 2005. Proses Praproduksi Sebagai Faktor Penting dalam Menghasilkan Produk Ternak yang Aman untuk Manusia. Jurnal Litbang Pertanian. 24:27-35.

Brooks, G. F., K. C. Carroll, J. Butel, S. A. Morse, \& T. Mietzner. 2013. Medical Microbiology. 26th edition. Mc Graw Hill. Available from: http://microbiology.sbmu.ac.ir/uploads/ja wetz_2013_medical_miceobiology.pdf

CLSI. 2017. M100 Performance Standards for Antimicrobial. 27th ed. Clinical and Laboratory Standards Institute, USA. Available from: $\underline{w w w . c l s i . o r g}$

Effendi, M. H., I. G. Bintari, E. B. Aksoro, \& I. P. Hermawan. 2018. Detection of blaTem Gene of Klebsiella pneumoniae Isolated from swab of food-producing animals in East Java. Tropical Animal Science Journal. $\quad$ 41:174-178. doi:10.5398/tasj.2018.41.3.174.

Erviani, A. E. 2013. Analisis Multidrug Resistensi Terhadap Antibiotik Pada Salmonella typhi Dengan Teknik Multiplex PCR. Biogenesis. 1:51-60.

Evans, D.J., and D.G. Evans. 1996. Medical Microbiology: Chapter 25 Escherichia coli in Diarrheal Disease - Medical Microbiology - NCBI Bookshelf. 4th edition. (S. Baron, editor.). Texas Medical Branch at Galveston, Texas. Available from:

https://www.ncbi.nlm.nih.gov/books/NBK 7710/?report=reader

Faishol, A. 2012. Potensi daerah Kabupaten Blitar. Available from: http://www.blitarkab.go.id/2012/06/15/pet ernakan-2/

Filho, H. C. K., K. C. T. Brito, L. S. Cavalli, \& B. G. Brito. 2015. Avian Pathogenic Escherichia coli (APEC) - an update on the control. The battle against microbial pathogens: Basic science, technological advances and educational programs. 598618.

Available

from:

http://www.microbiology5.org/microbiolo gy5/book/598-618.pdf

Handayani, R. S., S. Siahaan, \& M. J. Herman.
2017. Resistensi Antimikroba dan Penerapan Kebijakan Pengendalian di Rumah Sakit di Indonesia. Jurnal penelitian dan pengembangan pelayanan kesehatan. 1:131-140. Available from: http://ejournal.litbang.depkes.go.id

Iqbal, M. 2016. Strategi Penguatan Kinerja Pelayanan Kesehatan Hewan dalam Mendukung Sistem Kesehatan Hewan Nasional. Analisis Kebijakan Pertanian. 9:53. doi:10.21082/akp.v9n1.2011.53-71

Kusuma, A., and D. E. Waturangi. 2007. Studi Bakteri Fakultatif Metilotrof Berpigmen Merah Muda dari Tempat Berair: Resistensi Terhadap Klorin dan Antibiotik serta Deteksi Gen mxaF. Fakultas Teknobiologi. Universitas Katolik Atma Jaya.

Larson, E. 2013. Monitoring hand hygiene: Meaningless, harmful, or helpful. American Journal of Infection Control. 41:S42-S45. doi:10.1016/j.ajic.2012.09.029.

Martin, S. W., A. H. Meek, and P. Willeberg. 1987. Veterinary Epidemiology Principles and Methods. First edit. Iowa State University Press, Ames, United States of America.

Masruroh, C. A., M. B. Sudarwanto, \& H. Latif. 2016. Tingkat Kejadian Escherichia coli Penghasil Extended Spectrum B Lactamase yang Diisolasi dari Feses Broiler di Kota Bogor. Jurnal Sain Veteriner. 34:42-49.

Niasono, A. B., H. Latif, \& T. Purnawarman. 2019. Resistensi Antibiotik Terhadap Bakteri Escherichia coli yang Diisolasi dari Peternakan Ayam Pedaging di Kabupaten Subang, Jawa Barat. Jurnal veteriner. 20:187-195. doi:10.19087/jveteriner.2019.20.2.187

Paterson, D. L., \& R. A. Bonomo. 2005. Extended Spectrum Beta-Lactamases: a Clinical Update. Clinical Microbiology Reviews. 18:657-686. doi:10.1128/CMR.18.4.657.

Sumiarto, B., and S. Budiharta. 2018. Epidemiologi Veteriner Analitik. Gadjah Mada University Press, Yogyakarta. Wahyuwardani, S., S. M. Noor, M. Andriani, \& 
T. Aryanti. 2014. Kasus Kolibasilosis pada Peternakan Ayam Pedaging di Yogyakarta dan Bogor. Seminar Nasional Teknologi Peternakan dan Veteriner. Available from: http://peternakan.litbang.pertanian.go.id/f ullteks/semnas/pro14-93.pdf?secure=1

WHO. 2018. Escherichia coli. Available from: http://www.who.int/news-room/factsheets/detail/e-coli

Wibisono, F. J., B. Sumiarto, and T. A. Kusumastuti. 2018. Economic losses estimation of pathogenic Escherichia coli infection in Indonesian Poultry Farming. Buletin Peternakan. 42:341-346. doi:10.21059/buletinpeternak.v42i4.37505. Wiedosari, E., \& S. Wahyuwardani. 2015. A Case Study on the Diseases of Broiler Chicken in Sukabumi and Bogor Districts. Jurnal kedokteran hewan. 9:9-13. Available from: http://download.portalgaruda.org/article.p $\underline{\mathrm{hp}}$ ?article $=373423 \& \mathrm{val}=3946$. 